\title{
АНАЛІЗ СУЧАСНИХ ДОСЛІДЖЕНЬ РЕФЛЕКСІЇ
}

Стаття присвячена аналізу тематики та напрямків сучасних досліджень рефлексї у зарубіжній та вітчизняній психології. Показано, щзо витоки сучасних психологічних уявлень про рефлексію сформувалися у традищї філософської думки від античних часів. Складність сучасних умов розвитку актуалізує дослідження рефлексї та зумовлює різноманітність тематики. Рефлексію вивчають як механізм духовно-морального становлення особистості, як чинник вікового розвитку, як системоутворювальну якість професіоналів у різних сферах, як механізм навчання, професійної підготовки, особистісного та професійного зростання. Констатовано, щуо новітні дослідження рефлексії не структуровані на окремі иілісні школи. Перспективи подальших розвідок пов'язані з аналізом соціокультурної та особистісної рефлексії як ресурсів усвідомлення та подолання природних та соціальних криз. 
Ключові слова: рефлексія, рефлексивно-психологічні технології, рефлексивні практики, рефлексивний аналіз, групова рефлексія, стимули для рефлексії, ситуативна рефлексія, рефлексивна свідомість, рефлексивна компетентність.

Статья посвящена анализу тематики и направлений современных исследований рефлексии в зарубежной и отечественной психологии. Показано, что истоки современных психологических представлений о рефлексии сформировались в традиции философской мысли, начиная с античных времен. Сложность современных условий развития актуализирует исследования рефлексии и обуславливает разнообразие тематики. Рефлексию изучают как механизм духовно-морального становления личности, как фактор возрастного развития, как системообразующее качество профессионалов в разных сферах, как механизм обучения, профессиональной подготовки, личностного и профессионального развития. Констатировано, что новейшие исследования рефлексии не структурированы на отдельные целостные школь. Перспективы дальнейших исследований включают анализ сочиокультурной и личностной рефлексии как ресурса осознания $и$ преодоления природных и социальных кризисов.

Ключевые слова: рефлексия, рефлексивно-психологические технологии, рефлексивные практики, рефлексивный анализ, групповая рефлексия, стимуль для рефлексии, ситуативная рефлексия, рефлексивное сознание, рефлексивная компетентность.

Постановка проблеми. Історичні наукові передумови становлення психології рефлексії формувалися упродовж багатьох століть у межах філософської думки: у розмірковуваннях античних філософів Арістотеля, Сократа, Платона; в уявленнях середньовічних філософів (Августин, Фома Аквінський) про рефлексію як спосіб існування божественного розуму, як форму його реалізації; у переконаності мислителів епохи Відродження, що рефлексія необхідна для осмислення духовності людини; в інсайтах Декарта, який, власне, започаткував використання терміну «рефлексія» у науковому словнику; у «психологізації» поняття у роботах Дж. Локка, який визначав рефлексію як особливе джерело знань, що породжується внутрішнім досвідом; у контексті проблем гносеології у філософії XVII-XIX ст. як своєрідне джерело нових знань (Кант, Гегель, Фіхте); у контексті багатоманітності та мінливості життя, його саморуху та особистісної зумовленості, проблеми становлення Я і досвіду самопізнання у філософії життя (Шопенгауер, Ніцше, Гуссерль, Дільтей) та екзистенціалізмі (Сартр, Марсель, Камю). Як зауважує В.А. Роменець [7, с.73], рефлексія існує стільки ж часу, скільки людина ставить перед собою світоглядні питання з людськими проблемами в їхньому центрі. Таким чином, у філософській традиції рефлексія означає природну та необхідну людську здатність до розмірковування над собою та оточуючим світом. Таке розуміння рефлексії було сприйняте психологією, на сучасному етапі розвитку якої проблема рефлексії розглядається як одна з найбільш значущих. Розкриття іiї феноменів, механізмів та процесів пов'язане 3 вивченням фундаментальних проблем загальної, соціальної, вікової та педагогічної психології.

Власне психологічні дослідження рефлексії розпочалися лише у другій половині XX століття. Розвиток психології рефлексії як окремої галузі пов'язують з ім'ям вченого радянського періоду, а пізніше емігранта, В. Лефевра. Саме цей науковець у своїх фундаментальних роботах з системної методології та інженерної психології розробив оригінальні методи та моделі дослідження взаємодії партнерів у ситуаціях конфліктного протистояння. Перша в СРСР кандидатська дисертація 3 проблеми рефлексії була захищена саме В. Лефевром.

Аналіз останніх досліджень і публікацій. Реалії сучасного світу створюють запит на подальші фундаментальні та прикладні дослідження рефлексії, результати яких можна ефективно використовувати у соціальній практиці. Оскільки вивчення рефлексії як психологічної реальності розпочалося відносно недавно, то значущими для сучасної психології є теоретико-методологічні роботи, які показують перехід від рефлексії як філософської категорії до власне психологічного поняття ( І.Д. Бех). Дослідження рефлексивно-психологічних технологій навчання та професійної підготовки фахівців у різних галузях $\epsilon$, безумовно, актуальними у сучасних реаліях, що зумовлює інтерес науковців до цих аспектів проблеми (К. Zeichner, S. Kemmis, Sh. Edward, W. T. Branch, B. Molewijk, E. Gjerberg, L. Lillemoen, R. Pedersen). Психологічна сутність рефлексії зумовлює ії роль як центральної професійно-важливої якості фахівців у різних сферах (М. М. Марусинець, І.В. Остапенко). Цікаві та актуальні дослідження І.В. Яворської-Вєтрової, О.А. Краєвої, О.І. Зімовіна розкривають значення рефлексії як чинника вікового розвитку. Актуальними також є соціальнопсихологічні контексти рефлексії у роботах Л.М. Найдьонової та С.В. Сахно. Окремої уваги заслуговує дослідження рефлексії у зв'язку 3 розвитком новітніх технологій, які відривають 
практично необмежені можливості, але водночас містять і загрозливі для людини ризики (S. Roeser, V. Alfano, C. Nevejan).

Тому метою цієї статті є спроба аналізу тематики та напрямків сучасних досліджень у галузі психології рефлексії.

Виклад основного матеріалу дослідження. Аналіз зарубіжних наукових публікацій 3 психології рефлексії показує, що у центрі уваги дослідників знаходяться саме прикладні аспекти проблеми. Рефлексію досліджують у контексті професійної підготовки фахівців у різних сферах діяльності.

Так, K. A. Zeichner вказує на те, що сама ідея рефлексії у професійній діяльності педагога та у процесі його підготовки була абсолютно новаторською у північноамериканській психології ще 30 років тому, оскільки на час перших публікацій автора у 1981 році в освіті майбутніх вчителів домінував поведінковий підхід. Вважали, що головне завдання вчителя - це забезпечення високих результатів учнів у стандартизованих тестах, тому акцент робили на формуванні готовності до певних схем поведінки. Саме мислення вчителя, його здатність до аналізу підстав власних дій та вибору різних стратегій навчання відповідно до постійно змінюваних умов діяльності залишалося поза увагою [15]. Проте, зазначає K. А. Zeichner, упродовж останніх 30-35 років було обгрунтовано необхідність рефлексивного підходу у підготовці майбутніх педагогів. Вчитель, відповідно до цього підходу, розглядається не як практик, а як практик, котрий рефлексує. Рефлексія виводить практика за межі простого застосування певних методів та методик і дозволяє аналізувати причини їхнього вибору, враховуючи при цьому навчальні цілі, контекст ситуації, навчальні потреби учнів. Також автор підкреслює, що рефлексія є основою професійного самовдосконалення педагога. Ця здатність дозволяє аналізувати не тільки досвід інших, але й, насамперед, власний, оскільки «мудрість, яка грунтується на досвіді інших, є недостатньою» Важливим, на наш погляд, $є$ те що К. Zeichner розширює сферу рефлексії і виводить ії за межі педагогічного процесу. Він підкреслює, що вчитель має потужний вплив на учнів, а відтак - і на суспільство в цілому. Хоча дії вчителів у школах, очевидно, не можуть вирішити суспільні проблеми, проте вони можуть сприяти побудові більш справедливих та гідних суспільств. Найважливішим $є$ те, що навчання ніколи не може бути нейтральним. Викладачі повинні усвідомлювати суспільну значущість своїх повсякденних дій. Вони, можливо, не зможуть змінити деякі аспекти ситуації зараз, але принаймні вони будуть знати про те, що відбувається [15].

Подібні погляди розвиває S. Kemmis, який стверджує, що рефлексія неминуче є політичним актом, який або прискорює, або унеможливлює реалізацію більш гуманного, справедливого і гідного суспільства. Всі педагогічні дії мають різні наслідки, які включають: (1) особисті наслідки - вплив на соціальний та емоційний розвиток учнів та соціальні відносини; (2) академічні наслідки - навчальні досягнення на інтелектуальний розвиток учнів; і (3) політичні наслідки - сукупний вплив шкільного досвіду на життєві можливості учнів. Підсумовуючи, автор стверджує, що рефлексивна педагогічна освіта повинна охоплювати всі ці виміри, а ії глобальною метою є створення кращого суспільства для всіх дітей. На нашу думку, у контексті сучасних світових реалій ідеї K. Zeichner та S. Kemmis $€$ надзвичайно важливими. Вони закликають педагогів через усвідомлення цілей, способів та наслідків своєї діяльності стати частиною боротьби за соціальну справедливість, за доступ усіх дітей до засобів та умов, які допоможуть їм вести продуктивне та корисне життя.

S.Edwards аналізує роль рефлексії у процесі професійної підготовки медичних сестер. Залучаючи дані інших авторів, вона підкреслює важливість комплексного підходу у процесі навчання, у результаті якого студенти отримують теоретичні знання, а також практичний інтелект та практичну мудрість, які є не менш важливими, ніж теорія. Рефлексія, власне, розглядається як ланка, що поєднує теоретичне навчання та практику. Завдяки рефлексії студенти мають можливість аналізувати та узагальнювати свій професійний досвід, розуміти, які вони мають обмеження, що, у свою чергу, $є$ стимулом до подальшого навчання. Також використання рефлексивних практик дозволяє відслідкувати і зробити видимими ті унікальні індивідуальні способи, за допомогою яких фахівець досягає високого рівня майстерності [11]. Автор зазначає, що фахівці високого рівня, експерти у своїй галузі, досить часто приймають рішення у складних ситуаціях блискавично, так, що процес розмірковування та обгрунтування певного способу дій залишається «мовчазним», прихованим від інших. А це ускладнює практичну підготовку студентів. Тому автор наголошує на важливості багатовимірного розуміння рефлексії. У процесі навчання слід використовувати не тільки рефлексію поточну, у конкретній ситуації, але й рефлексію поза ситуацією. Це можна розглядати як ретроспективний аналіз випадків 3 практики, як процес обміну досвіду між експертами та студентами, що є стимулом для жвавих дискусій та створює сприятливе середовище для навчання [11]. Таким чином, теоретичне навчання поєднується 3 можливістю використовувати унікальний 
досвід експертів, а взаємодія з досвідченими практиками виступає як важливий навчальний ресурс. Водночас рефлексія $є$ механізмом самопізнання та самовдосконалення фахівця, забезпечує його професійне навчання упродовж всього життя. Отже, рефлексія власних дій є важливою умовою діяльності фахівця. У процесі практичної підготовки важливо розвивати не тільки цю здатність, але й створювати умови для рефлексивного аналізу досвіду експертів. А це, у свою чергу, сприятиме розвитку прогностичної рефлексії.

T. William. Jr Branch, M. George також звертаються до проблем підготовки майбутніх медиків й обгрунтовують ефективність рефлексивного навчання. Автори показують можливості керованої групової рефлексії з використанням наративів. Цей метод сприяє моральному розвитку і водночас сприяє формуванню професійної ідентичності у студентів. Вчені підкреслюють важливість становлення особистості медика як «гуманістичного клініциста», при цьому найвищий ступінь становлення особистості той, коли людина може вибрати для себе добрі моральні цінності та усвідомити і жити ними [10]. Таким чином, діяльність медиків актуалізує питання не тільки їхнього професіоналізму, але й іï морально-етичні аспекти. Особливо це стосується сфери охорони психічного здоров'я. Практика примусу й застосування обмежень існує в кожній країні світу, в певних межах ii використання легалізоване й санкціоноване в психіатричній практиці. Жодна держава наразі не запровадила повну заборону на застосування примусових (недобровільних) заходів медичного та виховного характеру. Водночас гострим є питання забезпечення належного рівня захисту суспільства від агресивних, протиправних, суспільно небезпечних дій (СНД) психічно хворих. В останні роки у світі спостерігається тенденція до зростання захворюваності на алкоголізм та гострі алкогольні психози, збільшується кількість осіб із психічними порушеннями органічного генезу. Останні посідають перше місце як серед тих осіб, які скоїли кримінальні дії та направляються на судово-психіатричну експертизу, так і серед тих хворих, які перебувають під наглядом психоневрологічних диспансерів. Тому професіонали служб охорони психічного здоров'я стикаються 3 багатьма етичними дилемами та складними ситуаціями, особливо якщо це передбачає застосування примусу.

M. Н.Нем, B.Molewijk, E.Gjerberg, L. Lillemoen, R. Pedersen досліджували ефективність участі фахівців у сфері охорони психічого здоров'я у групах етичної рефлексії. Аналіз 20 фокус-групових інтерв'ю 3127 учасниками показав, що більшість опитаних повідомляють про позитивний досвід участі в групах етичної рефлексії. Робота у таких групах забезпечує систематичний та добре структурований підхід до обговорення етичних проблем, спонукає до усвідомлення формального та неформального примусу, дає можливість оскарження проблемних концепцій, ставлень та практик, сприяє підвищенню професійної компетентності та довіри всередині команди, створює простір для внутрішньої критики та конструктивного аналізу розбіжностей, дозволяє визначити потенціал для вдосконалення та альтернативних напрямів діяльності. Автори показали, що групи етичної рефлексії мають потужний потенціал створення морального простору для професійної діяльності у сфері охорони психічного здоров'я [12].

Розвиток сучасних технологій, з одного боку, демонструє практично безмежність науковотехнічних можливостей людини, а з іншого - породжує нові ризики та актуалізує морально-етичні проблеми їх використання. Так, нейро-комп'ютерні інтерфейси відкривають нові можливості для відновлення втрачених функцій опорно-рухового апарату при аміотрофічному бічному склерозі, церебральному паралічі, інсульті або пошкодженнях спинного мозку. Ці системи здатні отримувати мозкові сигнали, аналізувати їх і перетворювати їх на команди, що ретранслюються на пристрої виведення, які, у свою чергу, виконують бажані дії. Використання нейро-комп'ютерних інтерфейсів дозволяє удосконалювати керування протезами, курсорами та іншими пристроями, що суттєво впливає на якість реабілітації пацієнтів 3 порушеннями опорно-рухового апарату. Для науковців, інженерів та клініцистів ці технології відкривають захопливі перспективи. Водночас виникають морально-етичні питання, які стосуються приватності, особистої ідентичності, припустимості експериментів на людях. S.Roeser, V. Alfano, C. Nevejan пропонують використовувати у публічних обговореннях ризикованих та суперечливих технологій твори мистецтва як стимули для емоційноморальної рефлексії. Автори описують досвід використання творів мистецтва, які ілюструють ці моральні проблеми, у дискусіях з учасниками «Хакатону». Як відомо, хакатон - захід, під час якого різні спеціалісти в галузі розробки програмного забезпечення інтенсивно і згуртовано працюють над розв'язанням певної проблеми). Зокрема, на Амстердамському хакатоні (червень 2016) обговорювалися питання нейро-комп'ютерного інтерфейсу. Мова йде про твори мистецтва, які використовують сучасні технології, зокрема, й нейро-компютерний інтерфейс. Наприклад, Ерген Маат створила «ЕЕГ-поцілунок»: дані електоенцефалограми двох людей, які цілуються, проектуються на екран, а публіка може спостерігати «портрет поцілунку». Споглядання графічного 
зображення активності мозку двох людей, які цілуються, може створити відчуття незручності i вуайєризму, але водночас може викликати цікавість та захоплення. Подібні твори мистецтва також викликають й етичні питання: якщо можна створити портрет інтимного поцілунку, який інший досвід (або характеристики) діяльності мозку можна візуалізувати за допомогою нейро-компютерного інтерфейсу [13]?

Інший приклад втручання технологій у фізичну недоторканість людини - експеримент художника Стеларка, який зв'язав свою нервово-м'язову систему з інтернетом у спектаклі "Body Ping". Присутні на фестивалях у різних європейських містах могли віддалено рухати його м'язами та змусили його танцювати. В результаті художник більше не міг контролювати власне тіло, був виснажений вимушеними рухами танцю. Це породжує питання про відповідальність. Якби Стеларк помер тоді і там, хто був би відповідальним. Таким чином, у дискусіях щодо морально-етичних проблем нейро-компютерних технологій твори мистецтва виступають як ресурс для рефлексії важливих питань: конфіденційності, інтелектуальної автономії, свободи волі, ідентичності. Один 3 учасників «Хакатону» порівняв твори мистецтва 3 «протезом для уяви», маючи на увазі, що суперечливі творіння викликають сильну емоційну реакцію: це може бути страх, гнів, відраза, надія, тощо, а це у свою чергу є потужним стимулом для рефлексії [13]?

Цікаві дослідження рефлексії здійснені останніми роками і в українській психології. Так, І.Д. Бех аналізує рефлексію у контексті їі духовно перетворювальних можливостей і виділяє чотири типи рефлексії: перший тип - регулятивна - метою якої є свідоме регулювання перебігу психічних процесів; другий тип - визначальна - за допомогою якої суб'єкт може усвідомити, чи відбулися якісь зміни у власній внутрішній особистій структурі. Синтезуюча рефлексія - третій тип, що полягає у зібранні сформованих духовних цінностей для створення образу Я особистості; до четвертого типу автор зараховує створювальну рефлексію, функцією якої $є$ моральний розвиток і саморозвиток особистості як об'єктивація власної самосвідомості. Виокремлені типи рефлексії розглядаються як вищі психічні механізми виховання духовних цінностей особистості, які в процесуальному розгортанні діють як послідовний перехід від свідомості до самосвідомості [1, с. 37-44].

I.В. Яворська-Вєтрова аналізує динаміку становлення ситуативної рефлексії на межі молодшого шкільного та підліткового віку, коли відбувається напруження процесів адаптації, зростають потреби у співвіднесенні своїх дій із ситуацією і коригування їх відповідно до змінюваних внутрішніх і зовнішніх умов та власних станів. Складовими ситуативної рефлексії, відповідно до поглядів автора, є аналіз і осмислення своєї діяльності, обдумування поведінки та коригування іiі відповідно до ситуації, самоконтроль. У дослідженні було встановлено, висока особистісна ефективність школярів прямо корелює з розвиненою ситуативною рефлексією й констатовано, що на межі переходу від молодшого шкільного до підліткового віку показники цього виду рефлексії нестабільні: як значне зниження у низькоефективних, так і стрибкоподібне підвищення у високоефективних учнів з певною позитивною стабілізацією їх у шестикласників [9].

О.А Краєва аналізує становлення рефлексивної свідомості на етапі подолання підлітком кризи ідентичності. Авторка розглядає особистісну рефлексію як механізм конструктивної самореалізації та саморозвитку, спрямований на подолання конфліктних і проблемних ситуацій індивіда. Їй вдалося окреслити дві основні тенденції у розвитку особистісної рефлексії: конструктивну та деструктивну. При цьому перша сприяє саморозвитку, самовдосконаленню особистості, друга, навпаки, гальмує ці процеси, пригнічує особистісний розвиток. Перехід від неусвідомлюваної до усвідомлюваної ідентичності можливий тільки за наявності рефлексії [3]. О.І. Зімовін аналізує рефлексію i креативність як чинники саморозвитку особистості, при цьому вони розглядаються як різноспрямовані: перша пов'язана із соціальним (етичним) спрямуванням саморозвитку, друга - 3 його орієнтацією на індивідуальний успіх. Автор встановив важливий зв'язок між рівнями рефлексії та креативності - показано, що найбільша організованість системи саморозвитку досягається при середніх значеннях особистісних рефлексії та креативності. Також встановлено закономірність у впливі рефлексії та креативності на саморозвиток особистості на різних вікових етапах, що зумовлено зміною життєвих завдань: початок самостійного життя вимагає проявів особистісної креативності; досягнення найвищої продуктивності - інтелектуальних рефлексії та креативності; інтеграція життєвого шляху - обох названих чинників [2].

Л.М. Найдьонова розглядає групову рефлексію як механізм реконструкції соціальних настановлень. Групова рефлексія - це метакогнітивна єдність відомих механізмів і процесів рефлексії, що здійснюються в інтерсуб'єктній взаємодії на різних рівнях ії цілісності. Групова рефлексія досвіду створення і змін коаліцій через усвідомлення належності і пост-належності різним груповим суб'єктам стає механізмом розв'язання ціннісних суперечностей у взаємодії суб'єктів, способом забезпечення повноти групового суб'єкта в значущій спільній події. У процесі 
реконструкції соціального настановлення відбувається рефлексивна активація когнітивного компоненту, спрямована на розбалансування системи настановлень, рефлексивна регуляція емоційного компоненту і переосмислення спільного поділеного досвіду [5]. М. М. Марусинець визначає рефлексію як системоутворювальний чинник професіоналізму вчителя. Педагогічна рефлексія є поєднанням трьох аспектів: пізнання, дії та переживання й характеризується як процес самопізнання в якості професіонала здійснювати аналіз особистісно-професійних знань, поведінки та переживань у педагогічній діяльності, а також усвідомлювати, як його сприймають інші суб'єкти навчально-виховного процесу [4].

Соціально-значущими є результати дослідження С.В. Сахно особливостей рефлексії жінок, засуджених до позбавлення волі. Було встановлено знижений іiі рівень розвитку; неадаптивну ідентичність у якій майже відсутній позитивний фон самосприймання; знижений фон саморозуміння; відсутність позитивних уявлень про себе у майбутньому, уявлень про себе як кохану жінку, дружину, працівника, професіонала, екзистенційних роздумів та переживань. Рівень аналізу своїх минулих помилок, досвіду і результатів своєї життедіяльності, а також і рефлексії ставлення іншої людини до себе в засуджених жінок $є$ зниженим. Аналіз причин, мотивів, що призвели жінку до скоєння злочину, не завжди ведуть до розкаяння. Планування майбутньої діяльності на певний час строку виконання покарань, $є$ невизначеним Установлено, що рівень розвитку рефлексії в жінок, засуджених до позбавлення волі, не залежить від типу скоєного злочину - насильницького чи корисливого. Для ефективної ресоціалізації, варто враховувати не покарання за злочин і ступінь його важкості, а саму особистість засуджених та інтегральну їі характеристику - рефлексію [8].

Предметом дослідження І.В. Остапенко є соціально-психологічні особливості формування рефлексивної компетентності топ-менеджерів. Рефлексивна компетентність топ-менеджерів розкривається в комплексі рефлексивно-особистісних, рефлексивно-інтелектуальних, рефлексивнокооперативних та рефлексивно-комунікативних компетентенцій. Рефлексивну компетентність пропонується розглядати як сукупність особистісних якостей, що забезпечують продуктивну рефлексію, яка у свою чергу розуміється як процес самопізнання, самоінтерпретації та самокорекції, a також пізнання та інтерпретації інших. У якості компонентів структури рефлексивної компетентності автор пропонує: розуміння себе та інших, система знань про способи розв'язання проблем у міжособистісній взаємодії, навички подолання проблемних ситуацій; вміння та навички саморегуляції у різних ситуаціях взаємодії, готовність до гнучкого використання набутого досвіду в реальних ситуаціях взаємодії [6].

Висновки 3 даного дослідження і перспективи подальших розвідок. Аналіз наукових публікацій, які торкаються теми рефлексії, показує, що діапазон їхньої проблематики надзвичайно широкий. Можна виокремити певні напрямки таких досліджень, а саме:

- дослідження рефлексії як професійно-важливої якості фахівців у різних галузях, як ресурсу особистісного та професійного зростання;

- дослідження рефлексивних технік навчання у процесі шкільної освіти та професійного навчання;

- дослідження рефлексії як чинника вікового розвитку;

- дослідження соціально-психологічних аспектів рефлексії;

- дослідження рефлексії як способу аналізу та оцінки ризиків у контексті розвитку інноваційних технологій

Можна констатувати, що ці дослідження ще не структуровані у формі чітко окреслених наукових шкіл на основі спільних методологічних засад, експериментальних методів і прикладних технологій. Водночас така різноманітність у дослідженнях рефлексії відкриває перспективи для подальших розвідок. Зокрема, це стосується соціокультурної рефлексії та прогностичної рефлексії як ресурсу для розробки адекватних політичних стратегій та тактик соціально-економічного розвитку, а також особистісної рефлексії як способу усвідомлення та переоцінки власного буття в умовах взаємно пов'язаних криз (природних та соціальних).

\section{Список використаних джерел}

1. Бех І. Д. Психологічні механізми сходження особистості до духовних цінностей / І. Д. Бех // Педагогіка і психологія. - 2011. - № 2. - С. 37-44.

2. Зімовін О. І. Рефлексія та креативність як чинники саморозвитку особистості на різних етапах життєвого шляху : автореф. дис. ... канд. психол. наук [Електронний ресурс] / О. І. Зімовін. Київ, 2017. - Режим доступу : http://ispp.org.ua/1493804538.zip 
3. Краєва О. А. Становлення рефлексивної свідомості на етапі подолання підлітком кризи ідентичності / А. О. Краєва // Проблеми сучасної психології : зб. наук. пр. Кам’янець-Поділ. нац. ун-ту ім. Івана Огієнка, Ін-ту психології ім. Г. С. Костюка НАПН України / за ред. : С. Д. Максименка, Л. А. Онуфрієвої. - Кам’янець-Подільський : Аксіома, 2011. - Вип. 11. - С. 382-392.

4. Марусинець М. М. Професійна діяльність педагога: рефлексивний аспект [Електронний ресурс] / М. М. Марусинець // Психолого-педагогічні проблеми сільської школи. - Режим доступу : http://nbuv.gov.ua/jpdf/Ppps_2012_43(1)__8.pdf

5. Найдьонова Л. М. Групова рефлексія як механізм реконструкції соціальних настановлень: дис. ... канд. психол. наук : 19.00.05 / Л. М. Найдьонова ; Нац. б-ка України ім. В. І. Вернадського. - Київ, 2014. - 245 с.

6. Остапенко I. В. Соціально-психологічні особливості формування рефлексивної компетентності топ-менеджерів : автореф. дис. ... канд. психол. наук [Електронний ресурс] / I. В. Остапенко. - Київ, 2014. - Режим доступу : http://ispp.org.ua/bibl_20.htm

7. Роменець В. А. Історія психології XX століття / В. А. Роменець, І. П. Маноха. - Київ, 1988. -992 c.

8. Сахно С. В. Особливості рефлексії жінок, засуджених до позбавлення волі : дис.... канд. психол. наук : 19.00 .05 / С. М. Сахно ; Ін-т психології ім. Г. С. Костюка НАПН України. - Київ, 2017. $-253 \mathrm{c}$.

9. Яворська-Вєтрова І. В. Динаміка становлення ситуативної рефлексії на межі молодшого шкільного та підліткового віку [Електронний ресурс] / I. В. Яворська-Вєтрова. - Режим доступу : http://www.appsychology.org.ua/data/jrn/v6/i12/28.pdf

10. Branch W. T. Reflection-Based Learning for Professional Ethical Formation [Electronic resource] / W. T. Branch, Maura George // AMA J Ethics. - 2017. - Apr 1; 19 (4). - S. 349-356. - URL : 10.1001/journalofethics.2017.19.4.medu1-1704.

11. Edwards Sh. Reflecting differently [Electronic resource] / Sh. Edwards // New dimensions: reflection-before-action and reflection-beyond-action : International Practice Development Journal. 7 (1) [2] fons.org/library/journal.aspx. - URL : https://doi.org/10.19043/ipdj.71.002

12. Hem M. H. The significance of ethics reflection groups in mental health care: a focus group study among health care professionals [Electronic resource] / M. H. Hem, B. Molewijk, E. Gjerberg // BMC Medical Ethics. - 2018. - URL : https://doi.org/10.1186/s12910-018-0297-y

13. Roeser S. The Role of Art in Emotional-Moral Reflection on Risky and Controversial Technologies: the Case of BNCI / S. Roeser, V. Alfano, C. Nevejan // Ethical Theory and Moral Practice. - 2018. - Vol. 21, Issue 2. - P. 275-289.|

14. Wocial L. D. Nurturing the moral imagination: a reflection on bioethics education for nurses [Electronic resource] / L. D. Wocial. - URL : https://doi.org/10.13153/diam.25.2010.407

15. Zeichner K. A critical analysis of reflection as a goal for teacher education [Electronic resource] / K. Zeichner // Educ. - 2008. - Vol. 29, № 103. - URL :http://dx.doi.org/10.1590/S010173302008000200012

\section{References}

1. Bekh I. D. Psykholohichni mekhanizmy skhodzhennia osobystosti do dukhovnykh tsinnostei / I. D. Bekh // Pedahohika i psykholohiia. - 2011. - № 2. - S. 37-44.

2. Zimovin O. I. Refleksiia ta kreatyvnist yak chynnyky samorozvytku osobystosti na riznykh etapakh zhyttievoho shliakhu : avtoref. dys. ... kand. psykhol. nauk [Elektronnyy resurs] / O. I. Zimovin. Kyiv, 2017. - URL : http://ispp.org.ua/1493804538.zip

3. Kraieva O. A. Stanovlennia refleksyvnoi svidomosti na etapi podolannia pidlitkom kryzy identychnosti / O. A. Kraieva // Problemy suchasnoi psykholohii : zb. nauk. pr. KPNU imeni Ivana Ohiienka, In-tu psykholohii im. H. S. Kostiuka NAPN Ukrainy. - 2011. - Vyp. 11. - S. 382-392

4. Marusynets M. M. Profesiina diialnist pedahoha: refleksyvnyi aspekt [Elektronnyy resurs] / M. M. Marusynets // Psykholoho-pedahohichni problemy silskoi shkoly. - URL : http://nbuv.gov.ua/jpdf/Ppps_2012_43(1)__8.pdf

5. Naidonova L. M. Hrupova refleksiia yak mekhanizm rekonstruktsii sotsialnykh nastanovlen : dys. ... kand. psykhol. nauk : 19.00.05 / L. M. Naidonova ; Nats. b-ka Ukrainy im. V. I. Vernadskoho. Kyiv, 2014. - $245 \mathrm{~s}$.

6. Ostapenko I. V. Sotsialno-psykholohichni osoblyvosti formuvannia refleksyvnoi kompetentnosti top-menedzheriv : avtoref. dys. ... kand. psykhol. nauk [Elektronnyy resurs] / I. V. Ostapenko. - Kyiv, 2014. - URL : http://ispp.org.ua/bibl_20.htm 
7. Romenets V. A. Istoriia psykholohii KhKh stolittia / V. A. Romenets, I. P. Manokha. - Kyiv, 1988. $-992 \mathrm{~s}$.

8. Sakhno S. V. Osoblyvosti refleksii zhinok, zasudzhenykh do pozbavlennia voli : dys. ... kand. psykhol. nauk : 19.00.05 / S. V. Sakhno ; In-t psykholohii im. H. S. Kostiuka NAPN Ukrainy. - Kyiv, 2017. $-253 \mathrm{~s}$.

9. Iavorska-Vietrova I. V. Dynamika stanovlennia sytuatyvnoi refleksii na mezhi molodshoho shkilnoho ta pidlitkovoho viku [Elektronnyy resurs] / I. V. Iavorska-Vietrova. - URL: http://www.appsychology.org.ua/data/jrn/v6/i12/28.pdf

10. Branch W. T. Reflection-Based Learning for Professional Ethical Formation [Electronic resource] / W. T. Branch, Maura George // AMA J Ethics. - 2017. - Apr 1; 19 (4). - S. 349-356. - URL : 10.1001/journalofethics.2017.19.4.medu1-1704.

11. Edwards Sh. Reflecting differently [Electronic resource] / Sh. Edwards // New dimensions: reflection-before-action and reflection-beyond-action : International Practice Development Journal. 7 (1) [2] fons.org/library/journal.aspx. - URL : https://doi.org/10.19043/ipdj.71.002

12. Hem M. H. The significance of ethics reflection groups in mental health care: a focus group study among health care professionals [Electronic resource] / M. H. Hem, B. Molewijk, E. Gjerberg // BMC Medical Ethics. - 2018. - URL : https://doi.org/10.1186/s12910-018-0297-y

14. Roeser S. The Role of Art in Emotional-Moral Reflection on Risky and Controversial Technologies: the Case of BNCI / S. Roeser, V. Alfano, C. Nevejan // Ethical Theory and Moral Practice. - 2018. - Vol. 21, Issue 2. - P. 275-289.|

15. Wocial L. D. Nurturing the moral imagination: a reflection on bioethics education for nurses [Electronic resource] / L. D. Wocial. - URL : https://doi.org/10.13153/diam.25.2010.407

16. Zeichner K. A critical analysis of reflection as a goal for teacher education [Electronic resource] / K. Zeichner // Educ. - 2008. - Vol. 29, № 103. - URL :http://dx.doi.org/10.1590/S010173302008000200012

\section{N.O. Iatsiuk ANALYSIS OF MODERN REFLECTION RESERCH.}

The article is devoted to the analysis of topics and areas of contemporary reflection research in foreign and domestic psychology. It is shown that the origins of modern psychological notions of reflexion were formed in the tradition of philosophical thought from ancient times. The complexity of modern conditions of growth actualizes the study of reflection and determines the diversity of subjects. The analysis of foreign scientific publications shows that works on the themes of reflection are mainly applied. The scientists pay considerable attention to the study of reflexive learning mechanisms, substantiate reflexive methods and techniques in the process of theoretical and practical training of specialists, especially physicians and educators. Also described is the use of reflexive techniques for improving professional activities and personal growth of professionals. The research of reflection and the search for its resources in a new field, such as an analysis of the risks of using innovative technologies, should be noted separately.

In the domestic psychology, there are solid theoretical and methodological studies of reflection as a mechanism of spiritual and moral formation of personality, as a factor of age development and various socio-psychological processes, as the key quality of professionals in various fields.

It was stated that the latest studies of reflection are not structured into separate holistic schools. Prospects for further research are related to the analysis of socio-cultural and personal reflection as a resource for awareness and overcoming natural and social crises.

Key words: reflection, reflexive-psychological technologies, reflexive practices, reflexive analysis, group reflection, stimuli for reflection, situational reflection, reflexive 